\title{
Assessment of Cypermethrin Residues in Tobacco by a Bioelectric Recognition Assay (BERA) Neuroblastoma Cell-Based Biosensor
}

\author{
Theofylaktos Apostolou ${ }^{1}$, Sophia Mavrikou ${ }^{1, *} \mathbb{0}$, Nikoleta-Kleio Denaxa ${ }^{2}$, Georgia Paivana ${ }^{1, *}$, \\ Peter A. Roussos ${ }^{2}$ and Spyridon Kintzios ${ }^{1}$ (D) \\ 1 Laboratory of Cell Technology, Department of Biotechnology, Faculty of Applied Biotechnology and Biology, \\ Agricultural University of Athens, Iera Odos 75, 11855 Athens, Greece; apostolou.theo@gmail.com (T.A.); \\ skin@aua.gr (S.K.) \\ 2 Laboratory of Pomology, Faculty of Crop Science, Agricultural University of Athens, Iera Odos 75, \\ 11855 Athens, Greece; nkdenaxa@gmail.com (N.-K.D.); roussosp@aua.gr (P.A.R.) \\ * Correspondence: sophie_mav@aua.gr (S.M.); georpaiv@gmail.com (G.P.); Tel.: +30-210-529-4292 (S.M.)
}

Received: 24 October 2019; Accepted: 16 November 2019; Published: 20 November 2019

\begin{abstract}
This study presents a bioelectric cell-based biosensor for the monitoring of the pyrethroid pesticide cypermethrin, a voltage-gated sodium channel blocker, in tobacco samples. For this purpose, neuroblastoma cells were used as biorecognition elements. The potential interference by the tobacco major alkaloid nicotine on the detection of cypermethrin was also studied. In addition, fluorescence microscopy revealed a specific pattern of neuroblastoma cell calcium efflux $\left(\mathrm{Ca}^{2+}\right)$ after treatment with nicotine or cypermethrin. Finally, actual field-derived tobacco extracts were used for assessing matrix effects on the biosensor's performance. The biosensor could detect cypermethrin in concentrations up to $1.5 \mu \mathrm{g} \mathrm{mL} \mathrm{g}^{-1}$ without being influenced by the presence of nicotine and possibly other tobacco alkaloids. Though not selective for cypermethrin, the neuroblastoma-based biosensor system appears to be a promising alternative to laborious analysis methodologies for rapid, high throughput and cost-efficient screening of this pyrethroid in tobacco samples in the near future.
\end{abstract}

Keywords: bioelectric recognition assay (BERA); cell-based biosensor; cypermethrin; neuroblastoma; nicotine; tobacco; quick; easy; cheap; effective; rugged; safe sample preparation technique

\section{Introduction}

The high environmental persistence of contaminants, including toxic heavy elements, antibiotics, and pesticides, either controlled or uncontrolled, is an issue of great concern due to its potential risk on biological systems, including pollinating insects, livestock and humans [1]. Pyrethroid pesticides, characterized by extreme low water solubility and environmental persistence have been widely used for insect control in agriculture and households. In vitro, in vivo, and in situ strategies constitute various assays and models for the evaluation of the assessment of toxicities caused by pyrethroid pesticides, toxic concentrations of which have been detected in various commodities as well as in surface and groundwater [2,3].

Pesticide residues may remain on tobacco leaves long after their processing (e.g., curing) into manufactured forms, especially due to their greater surface to weight ratio, relative to other species [4]. A representative insecticide used in tobacco cultivation is cypermethrin, a Type II of cyanophenoxybenzyl pyrethroid [5] and the cyano-3-phenoxybenzyl ester of "-2,2'-dimethylcycloporopane cyclopropane carboxylate. Depending on its initial concentration, length and frequency of exposure, cypermethrin may have considerable effects on human health and the environment. Mild acute toxicity in mammals is indicated by dizziness, paresthesia, itching, 
bronchospasm, vomiting and allergic reactions [6,7], while cypermethrin is highly toxic to fish [8]. On a cellular-molecular level, low toxicity of cypermethrin has been demonstrated in human dopaminergic neuroblastoma SH-SY5Y, human hepatoma HepG2 and human intestinal epithelial Caco-2 cell lines [9] and rat brain astrocytes [10]. Raszewski et al. [11] reported that cypermethrin-induced toxicity in SH-SY5Y neuroblastoma cells depends on the upregulation of the $\alpha$-tumor necrosis factor receptors (TNFR1), without being associated with other signaling pathways, such as caspase activation, extracellular-signal-regulated kinase (ERK), mitogen-activated protein kinases (MAPK/ERK kinases) (MEK), c-Jun N-terminal kinase (JNK) or p38 mitogen-activated protein kinase (MAPK). After profiling the expression of 84 genes involved in the apoptotic pathway of SH-SY5Y cells, Romero et al. [12] found that cypermethrin alters the expression of apoptosis, autophagy and necrosis genes in this particular cell line. Cypermethrin also displayed a concentration-dependent decrease of cell viability, cell morphology alterations and an increase of intracellular $\left[\mathrm{Ca}^{2+}\right]$ release, as well as ROS generation and MAPK signaling activation in primary cultures of rat astrocytes [13]. Although voltage-gated sodium channels are considered as the main targets of cypermethrin [14], low potency effects on calcium channels have been also reported for some neuronal cell lines, e.g., rat pheochromocytoma (PC12) cells [15,16]. Moreover, up to now, research has shown that cypermethrin influences calcium channels by activating the return transport of calcium ions $[14,17,18]$. In addition, apart from mammalian cell lines, several researchers have also reported the effects of cypermethrin applied to fish cells. Taju et al. [19] studied concentration-dependent cytotoxicity of cypermethrin in five fish cell lines after $24 \mathrm{~h}$ of treatment. The results revealed a significant increase in genotoxicity, oxidative stress and changes in cell shape.

As mentioned above, tobacco production requires the use of several pesticides during its cultivation. The assessment of the combined toxicological effects of pesticides with nicotine, the major tobacco alkaloid, is very difficult to evaluate. Many studies have indicated that low, nontoxic doses of nicotine improve cognitive performance through modulating the release of several neurotransmitters, including acetylcholine and dopamine [6,7]. In addition, nicotine application may act protectively against the development of Parkinson's disease [20,21]. The study of co-exposure to pesticides and nicotine is particularly interesting since both cholinesterase-inhibiting pesticides and nicotine have significant effects on cholinergic neurotransmission. Although pesticides increase cholinergic neurotransmission by blocking the degradation of the acetylcholine, nicotine, on the other hand, increases cholinergic neurotransmission by directly binding to the acetylcholine receptor.

The significant issues on human health caused by environmental pollution during the sustainable development of society have led to breakthroughs in biosensors' fabrication and development for the environmental monitoring of organic pollutants, potentially toxic elements, and pathogens. Conventional analytical techniques used for this purpose include several chromatographic methods, such as gas chromatography and/or high-performance liquid chromatography coupled with mass spectrometry or capillary electrophoresis. Nevertheless, these methods necessitate time-consuming sample pretreatment, highly trained personnel as well as high-cost reagents and equipment [22,23]. Hence, environmental pollutant monitoring requires more sensitive, user-friendly, quick, cheap and portable biosensing instrumentation, with field test-oriented capabilities.

A couple of biosensor-based methodological approaches have been developed as an alternative to current in vitro assays for the assessment of cypermethrin toxicity in mammals and other species. A common denominator in all these methods is the desire to achieve a rapid test at a low cost, preferably allowing for high throughput. In the majority of said approaches, the measurement of cellular electrophysiological/bioelectric properties is the working principle. In the early study by Natarajan et al. [20], titanium nitride microelectrode arrays (MEAs) on glass were used to extracellularly monitor the beating of chick embryonic cardiac myocytes plated at a density of 400,000 cells/mL. Signal synchronization among cells and stabilization between days 3 and 6 was required before measuring the actual effect of cypermethrin and other pyrethroids over a period of 3-4 h. All investigated compounds caused a drastic decrease in the extracellularly recorded action potentials. In addition, Farré et al. [21] compared testing results of the acute toxicity of cypermethrin derived either with 
CellSense, an amperometric biosensor that measures the electrical current produced by the electron transport chain of Pseudomonas putida (ST02/I.NB/280300) or with the ToxAlert 100 system, which measures the bioluminescence inhibition of Vibrio fischeri NRRL B-11177. A narrower linear range of detection but greater sensitivity was determined for the amperometric approach, which required $15 \mathrm{~min}$ of exposure to cypermethrin. Quite recently, Moschopoulou et al. [24] reported the application of a dual amperometric/potentiometric biosensor approach for the differential monitoring of the response of four different mammalian cell lines (two kidney, two neuroblastoma) against mixtures of pyrethroids, including cypermethrin. For this purpose, the authors applied a modification of the Bioelectric Recognition Assay (BERA) [20,25]. According to the BERA working principle, whole, functional, living cells immobilized in a hydrogel matrix are connected with a sensor assembly in order to identify alterations of the cellular electric properties. Cells specific interaction with a target analyte such as pesticides, drugs or xenobiotics leads to the generation of a unique cellular electrical potential motif [25]. The BERA assay has been already been used for the detection of several pesticides (especially organophosphate and carbamates) in various food matrices [25-27]. In the study conducted by Moschopouolou et al. [24], the authors were able to determine a unique pattern of response for each cell type, with amperometry being more reproducible than potentiometry. The pyrethroid mixture caused a concentration-dependent increase of bioelectric conductivity in neuroblastoma SK-N-SH cells, as wells as a considerable decrease in neuroblastoma N2a and kidney Vero cells. No substantial change of conductivity was recorded on kidney HaK cells.

In this study, we have developed a neuroblastoma cell-based bioelectric sensor in order to determine cypermethrin residues in tobacco samples. Pyrethroids, including cypermethrin, prolong the opening of sodium channels in the central nervous system leading to depolarization and hyper-excitation of the neurons $[12,13]$. Therefore, the potential interference of the acetylcholine receptor agonist nicotine on the detection of the neurotoxic insecticide cypermethrin was also assessed. In addition, neuroblastoma cell calcium uptake $\left(\mathrm{Ca}^{2+}\right)$ after treatment with nicotine and cypermethrin was fluorometrically determined. Finally, actual field-derived tobacco extracts were received with the Quick Easy Cheap Effective Rugged Safe method (QuEChERS) and assayed for cypermethrin residues.

\section{Materials and Methods}

\subsection{Biological and Chemical Materials}

Human neuroblastoma SK-N-SH (ATCC ${ }^{\circledR}$ HTB-11 ${ }^{\mathrm{TM}}$ ) cell cultures were originally provided from LGC Promochem (LGC Standards, Teddington, UK) and subcultured in Dulbecco's Medium with $10 \%$ fetal bovine serum (FBS) (Thermo Fisher Scientific, Waltham, MA, USA), $1 \mathrm{U} \mathrm{mg}^{-1}$ antibiotics (penicillin/streptomycin) and 2mM L-glutamine (Biowest, Nuaille, France). A commercial formulation of cypermethrin (Fluka-PESTANAL, Seelze, Germany) was used for preparing standard pesticide solutions daily in double-distilled water. The experimental procedure was followed by the European Method EN 15662. QuEChERS extraction was performed using the Bond Elut QuEChERS P/N 5982 extraction kit containing $4 \mathrm{~g} \mathrm{MgSO}_{4}, 1 \mathrm{~g} \mathrm{NaCl}, 1 \mathrm{~g} \mathrm{NaCitrate}, 0.5 \mathrm{~g}$ disodium citrate sesquihydrate. A dispersive solid-phase extraction salt and sorbent kit were tested; Bond Elut QuEChERS part number $(\mathrm{P} / \mathrm{N})$ 5982-5221 containing $25 \mathrm{mg}$ prostate specific antigen (PSA), $2.5 \mathrm{mg}$ graphitized carbon black (GCB), and $150 \mathrm{mg} \mathrm{MgSO}$ (Agilent Technologies, Lake Forest, CA, USA). Fluo-3 fluorometric dye was obtained from Invitrogen (Carlsbad, CA, USA). All other reagents were purchased from Sigma-Aldrich (Taufkirchen, Germany).

\subsection{Sample Preparation for the Cell-Based Biosensor Assessment}

Organic tobacco leaf samples were provided by local producers in Greece in the year 2015. A two (2) g sample of tobacco was weighed into a $50 \mathrm{~mL}$ centrifuge tube and $10 \mathrm{~mL}$ organic-free water was added. Acetonitrile $(10 \mathrm{~mL})$ was then added into the centrifuge tube, followed by a ceramic homogenizer, and the QuEChERS extraction salt packet (EN 15662: $4 \mathrm{~g} \mathrm{MgSO}_{4}, 1 \mathrm{~g} \mathrm{NaCl}, 1 \mathrm{~g}$ 
NaCitrate, $0.5 \mathrm{~g}$ disodium citrate sesquihydrate) (Agilent, Santa Clara, CA, USA) [21,28]. The tube was immediately sealed and shaken vigorously by hand for $1 \mathrm{~min}$. The tube was then centrifuged for $5 \mathrm{~min}$ at $3000 \mathrm{~g}$. The top acetonitrile layer was collected and aliquots were taken for subsequent cleanup. The dispersive solid-phase extraction salt and sorbent kit Bond Elut QuEChERS P/N 5982-5221 (Agilent, Santa Clara, CA, USA) was used. For cleanup, a $1 \mathrm{~mL}$ aliquot of each extract was added to the dispersive solid-phase extraction tubes, which were gently shaken for $2 \mathrm{~min}$ and then centrifuged for $5 \mathrm{~min}$ at $3000 \mathrm{~g}$. A $0.5 \mathrm{~mL}$ portion of the supernatant extract was placed into a glass centrifuge tube and then evaporated to dryness under a stream of nitrogen. Finally, the residue was redissolved in $10 \%$ methanol.

\subsection{Cell Membrane Potential Measurements: Biosensor Set-Up}

Changes of the cell membrane potential were measured using a customized, multichannel potentiometer (EMBIO DIAGNOSTICS Ltd., Nicosia, Cyprus), operating according to the principle of the Bioelectric Recognition Assay (BERA). The device measures the actual availability (binding and/or uptake) of analytes through changes of the membrane potential and other electric properties of the cells in a highly fast, sensitive, high throughput and reproducible fashion. The low-power amplifier in the device is able to measure small differential voltage with high common-mode voltage developed between the noninverting and inverting input [29]. Therefore, the system is able to provide real-time changes of the electric properties of cells from up to eight simultaneous measurements from respective eight carbon screen-printed electrodes (working electrode: carbon, reference: $\mathrm{Ag} / \mathrm{AgCl}$ ) on a disposable sensor strip (Gwent, UK) (Figure 1).
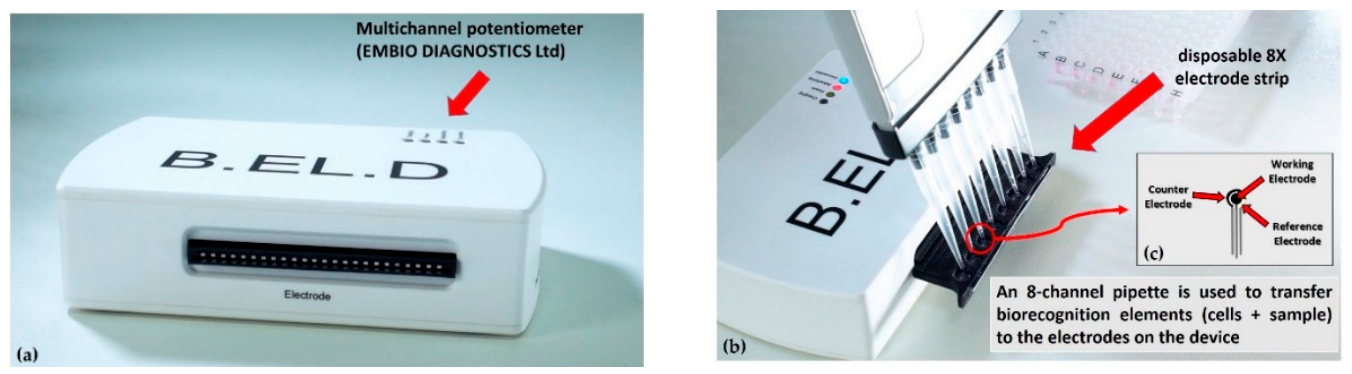

Figure 1. Experimental setup of the cell-based biosensor's assembly. Multichannel potentiometer device (a), connection of the potentiometer with the screen printed eight-channel electrode (b).

Neuroblastoma cells (SK-N-SH) were cultivated in at $37{ }^{\circ} \mathrm{C}$ and in $5 \% \mathrm{CO}_{2}$. After trypsinization, cells were detached from the culture flask and concentrated by centrifugation $\left(2 \mathrm{~min}, 1200 \mathrm{rpm}, 25^{\circ} \mathrm{C}\right)$. Cells in suspension were added first on the top of each of the eight carbon screen-printed electrodes contained in each disposable sensor strip ( $45 \mu \mathrm{L} \approx 50 \times 10^{3}$ cells) with the help of a multichannel automatic pipette. Then, $5 \mu \mathrm{L}$ of the sample (either standard solution of the pesticide or tobacco extract) were added, and the response of cells was immediately recorded as a time-series of potentiometric measurements (in Volts). Each measurement lasted $180 \mathrm{~s}$ and 360 values/sample were recorded at a sampling rate of $2 \mathrm{~Hz}$. The biosensor's response was expressed according the following Equation (1):

$$
\% \text { Normalized Biosensor Response }=\left(\frac{\text { Mean } S}{\text { Mean C }}\right) * 100
$$

where Mean S stands for the Mean Value of the Sample tested and Mean C is the Mean Value of the Control Sample that does not contain the analyte.

\subsection{Intracellular $\mathrm{Ca}^{2+}$ Uptake Analysis by Fluorescence Imaging}

The concentration of $\left[\mathrm{Ca}^{2+}\right]_{\mathrm{i}}$ was measured with Fluo-3/AM probe [30]. $10^{5} \mathrm{SK}-\mathrm{N}-\mathrm{SH}$ cells were cultured in well plates for $24 \mathrm{~h}$ in order to adhere on the plate's surface. The next day the medium 
was replaced with a serum-free medium containing cypermethrin, nicotine standards and/or tobacco extracts and the cells were incubated in a cell culture chamber for $30 \mathrm{~min}$. Then, neuroblastoma cells were incubated with $5 \mu \mathrm{M}$ Fluo-3/AM in the dark for $30 \mathrm{~min}$ at $37^{\circ} \mathrm{C}$, the medium was removed and cells were washed with phosphate-buffered saline (PBS) three times to remove the nonspecific staining. The treated cells were observed using a phase-contrast fluorescence microscope (ZEISS Axio Vert. A1, Carl Zeiss Microscopy, LLC, White Plains, NY, USA) with $506 \mathrm{~nm}$ excitation and $526 \mathrm{~nm}$ emission. At least three independent samples were analyzed for each experimental group.

\subsection{Nicotine Chemical Analysis}

Nicotine determination was performed with the Shimadzu Nexera X2 high performance liquid chromatography (HPLC) system (Kyoto, Japan) equipped with LC-30AD pump, degassing unit DGU-20A 5R degasser, sample injection SIL-30AC autosampler, CTO-20 AC column oven and SPD-M20A UV-VIS detector, based on the method described by Tambwekar et al. [31] with modifications. The separation was done on a Discovery ${ }^{\circledR} \mathrm{C} 18$ column $(25 \mathrm{~cm} \times 4.6 \mathrm{~mm}, 5 \mu \mathrm{m})$ (Merck, Darmstadt, Germany), at $28{ }^{\circ} \mathrm{C}$ and eluted at a flow rate of $0.5 \mathrm{~mL} \mathrm{~min}{ }^{-1}$. The isocratic mobile phase used was a mixture of $10 \mathrm{mM}$ phosphate buffer pH 7.5 and methanol (HPLC grade) at a ratio of 80:20 v/v. The nicotine content was detected and quantified by the absorbance at $259 \mathrm{~nm}$ with a PDA detector in duplicate. Standard nicotine was purchased from Fluka-PESTANAL (99.1\%) (Seelze, Germany). A stock solution of nicotine $\left(1 \mathrm{mg} \mathrm{mL}^{-1}\right)$ was prepared by dissolving $100 \mathrm{mg}$ in $100 \mathrm{~mL}$ of phosphate buffer ( $\mathrm{pH} 7.5)$. Various dilutions $\left(2.5-50 \mu \mathrm{g} \mathrm{mL}^{-1}\right)$ were prepared in duplicate and used to construct the standard curve (assayed in quadruplicate). The retention time of nicotine was $\sim 3.93 \mathrm{~min}$.

\subsection{Data Analysis and Experimental Design}

Experiments were set up in a completely randomized design and each experiment was repeated three times with three replications $(n=3)$. In each application, a set of eight biosensors was tested against each individual sample. All results are expressed as the mean \pm the standard error of the mean (SEM). Differences between means were tested for statistical significance using a multiple Student's $t$-test. Significant differences were reported as adjusted $p$-values $<0.05$ (two-sided).

\subsection{Chromatographic Analysis of Cypermethrin Residues in Tobacco Leaves}

For cypermethrin detection in tobacco leaves, samples were cleaned up by florisil column chromatography [32]. Initially, activation of florisil (60-100 mesh) was performed at $200{ }^{\circ} \mathrm{C}$ for $6 \mathrm{~h}$ and the subsequent deactivation was carried out with $2 \% v / v$ distilled water. Firstly, the florisil column was packed with anhydrous sodium sulfate. Then, a solvent mixture of double distilled hexane (65\%) and dichloromethane $(35 \%)$ at $5 \mathrm{~mL} \mathrm{~min}^{-1}$ was applied in order to elute the compounds of interest and the extract was dried with a rotary vacuum evaporator. After transfer in a new vial, extraction under a gentle flow of nitrogen followed for the complete solvent removal. The dried sample was finally dissolved in acetonitrile (ACN), and filtered through a syringe filter $(0.2 \mu \mathrm{m}$ pore size $)\left(\mathrm{Chromafil}{ }^{\circledR}\right)$.

For the HPLC analysis, a Shimadzu LC10 Avp-Series system was used, equipped with a SPD-M10 Avp, outfitted with a photodiode array (PDA) detector. The separation was performed at $30{ }^{\circ} \mathrm{C}$ on a Discovery ${ }^{\circledR} \mathrm{C} 18$ column $(25 \mathrm{~cm} \times 4.6 \mathrm{~mm}, 5 \mu \mathrm{m})$ (Merck, Darmstadt, Germany). The mobile phase used was $70 \% v / v \mathrm{ACN}$ in water, at a flow rate of $1.2 \mathrm{~mL} \mathrm{~min}^{-1}$. The isocratic mobile phase used was a mixture of $70 \% \mathrm{ACN}$ and $30 \%$ water, was allowed to run at $1.2 \mathrm{~mL} \mathrm{~min}{ }^{-1}$. The identification of cypermethrin was performed by comparing sample peak retention times with those of the pure analytical standard. Data analysis and quantification has been previously described [33]. The \% recoveries were calculated by the following Equation (2):

$$
\% \text { recovery }=\frac{C E}{C S} * 100
$$


where $\mathrm{CE}$ is the extract concentration determined from the calibration curve and CS is the concentration of the spiked sample.

\section{Results}

Neuroblastoma Cell-Based Biosensor Response against Cypermethrin Standard Solution

In order to evaluate the existing cell surface electrical charges caused by different cypermethrin concentrations $\left(0,0.3,0.7,1.0,1.5 \mathrm{\mu g} \mathrm{mL}^{-1}\right)$, we conducted measurements on an 8-carbon screen-printed electrode. According to the working principle of the BERA approach, the interaction of a target analyte with cells causes a change in cell membrane potential that is dependent upon the concentration of said analyte. In our experimental study, neuroblastoma SK-N-SH cells demonstrated exhibited a significantly decreasing response with increasing cypermethrin concentrations, especially in the range of $1.0-1.5 \mu \mathrm{g} \mathrm{mL}^{-1}$ (Figure 2).

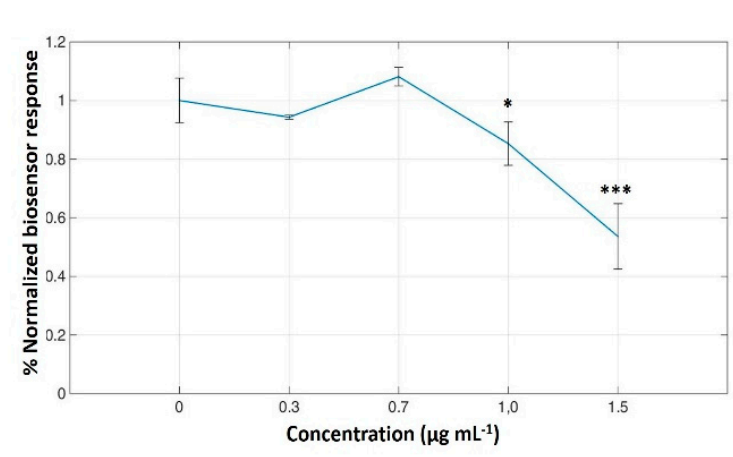

(a)

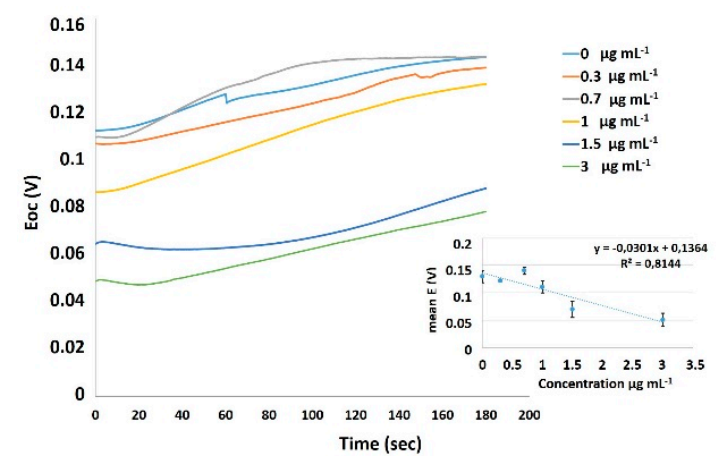

(b)

Figure 2. Normalized neuroblastoma cell-based biosensor electrical responses after application of increasing concentrations of cypermethrin $\left(0,0.3,0.7,1.0,1.5 \mu \mathrm{g} \mathrm{mL}^{-1}\right)$. The results are expressed as the percentage of the mean values \pm SD compared with the control, notated as $0 \mu \mathrm{g} \mathrm{mL}^{-1}(\mathrm{n}=3) .{ }^{*} p<0.05$, ${ }^{* * *} p<0.001$. (a) Open circuit potential (E) vs. Time (sec) curves for the visualization of the sensing properties of the biosensor platform. A calibration curve is placed at the right bottom of the plot (b).

The fluorescence of live fluo-3/acetoxymethyl ester (AM)-stained neuroblastoma cells was recorded with the aid of a reverse phase microscope. As shown in Figure 3, the application of cypermethrin $\left(1.5 \mu \mathrm{g} \mathrm{mL}^{-1}\right)$ on SK-N-SH cells resulted in a slight reduction of average cell size (Figure $\left.3 a, b\right)$ and increased intracellular calcium efflux (Figure 3c,d).

In order to study the combined effects of cypermethrin with the main tobacco alkaloid nicotine, we incubated neuroblastoma cells with a mixture of cypermethrin and nicotine in three different final concentrations $\left(300,1500,3000 \mu \mathrm{g} \mathrm{mL}^{-1}\right)$. As indicated in Figure 4, the neuroblastoma biosensor responses declined with the increase of nicotine concentrations, whereas this decreasing motive was disrupted when cypermethrin was introduced, especially at the highest nicotine concentration $\left(3000 \mu \mathrm{g} \mathrm{mL}^{-1}\right)$. Treatments with nicotine-cypermethrin mixtures significantly altered the cellular bioelectric responses by reducing the output signal as nicotine concentrations raised, reaching a plateau at $3000 \mu \mathrm{g} \mathrm{mL} \mathrm{L}^{-1}$. 

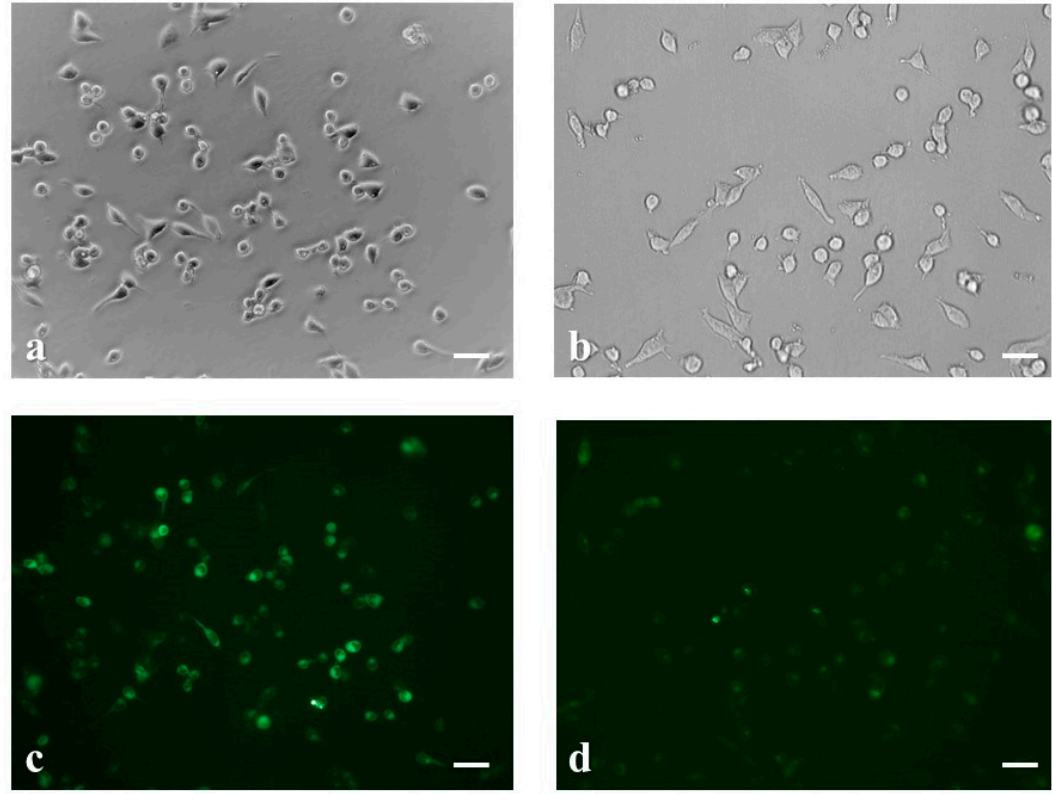

Figure 3. Microscopic examination of the morphological changes induced in neuroblastoma cells before (a) and after treatment with $1.5 \mu \mathrm{g} \mathrm{mL}^{-1}$ cypermethrin for $30 \mathrm{~min}$ (b). Fluorescence staining of SK-N-SH cells before (c) and after cypermethrin application revealed intracellular calcium efflux (d). Scale bars $=50 \mu \mathrm{m}$.

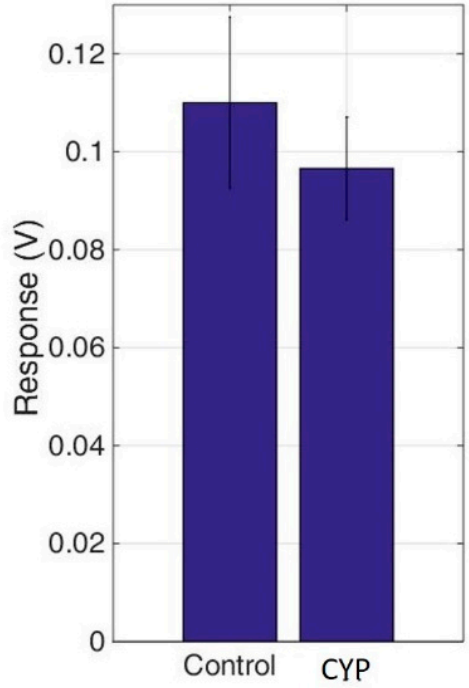

(a)

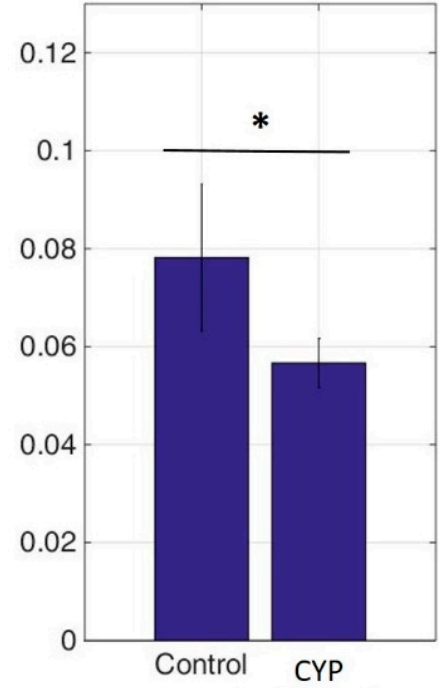

(b)

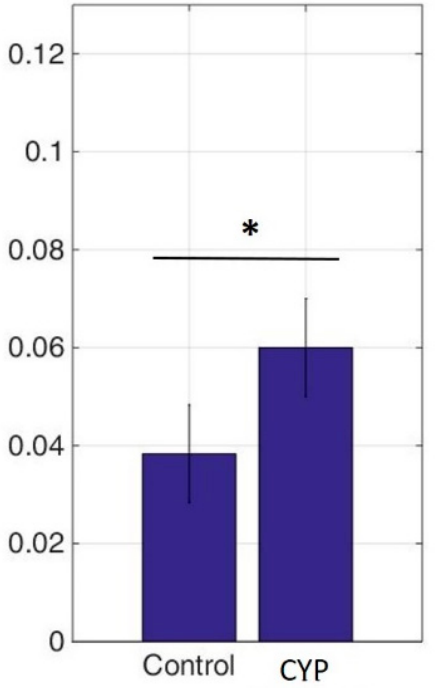

(c)

Figure 4. Neuroblastoma cell-based biosensor electrical responses after application of increasing concentrations of nicotine ((a): 300, (b): 1500, (c): $3000 \mu \mathrm{g} \mathrm{mL}^{-1}$ ) either alone (control) or in combination with $1.5 \mu \mathrm{g} \mathrm{mL}^{-1}$ cypermethrin. The results are expressed as the mean values of five replications $\pm \mathrm{SD}$. $\mu \mathrm{g} \mathrm{mL} \mathrm{m}^{-1} .{ }^{*} p<0.05$.

In the meantime, incubation of the cells with the abovementioned concentrations of nicotine for half an hour, had significant effects on both cell viability and intracellular calcium levels (Figure 5). We observed that low doses of nicotine $\left(300 \mu \mathrm{g} \mathrm{mL}^{-1}\right)$ had minor impact on cellular morphology and calcium flux in comparison with higher concentrations $\left(1500 \mu \mathrm{g} \mathrm{mL}{ }^{-1}\right)$, where we noticed excessive cytotoxicity and depletion of intracellular calcium inventories. 
Previous studies reported that nicotine content in cigarette tobacco varies from 0.5 to $19.5 \mathrm{mg} \mathrm{gr}^{-1}$. In our work, the analysis of the tobacco extracts used as cypermethrin negative control revealed that they contained $\sim 4.67 \mathrm{mg} \mathrm{gr}^{-1}$ nicotine, which is within the specific concentration range mentioned above [34,35].
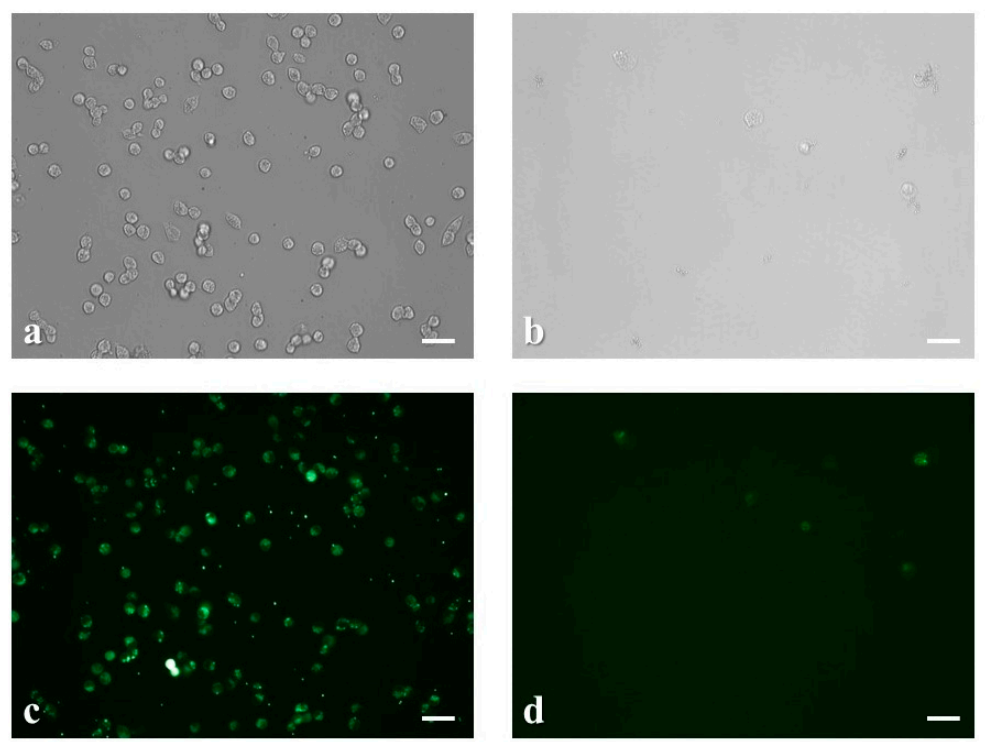

Figure 5. Microscopic examination of the morphological changes induced in neuroblastoma cells after treatment with $300 \mu \mathrm{g} \mathrm{mL} \mathrm{m}^{-1}$ (a) and $1500 \mu \mathrm{g} \mathrm{mL} \mathrm{m}^{-1}$ nicotine for $30 \mathrm{~min}$ (b). Calcium fluorescence staining ofneuroblastoma SK-N-SH cells after application of $0.3 \%$ (c) and $1.5 \%$ nicotine for $30 \mathrm{~min}$ (d). Scale bars $=50 \mu \mathrm{m}$.

The selected nicotine concentrations were based on the results of the standard curve of the cellular bioelectric responses prepared in a previous experimental set (Figure 6)

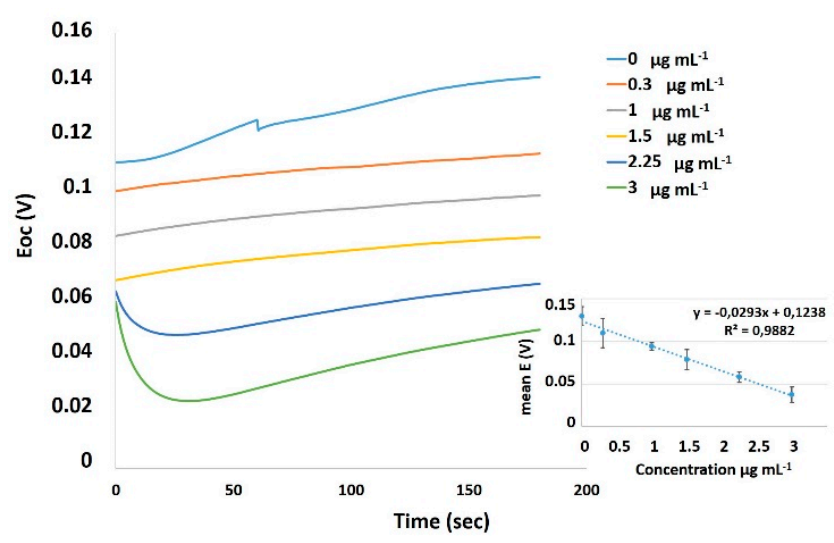

Figure 6. Open circuit potential (E) vs. Time (sec) curves of the cellular bioelectric responses after application of various nicotine concentrations $\left(0.3,1,1.5,2.25,3 \mu \mathrm{g} \mathrm{mL}^{-1}\right)$. A calibration curve is placed at the right bottom of the plot.

The biosensor's response was tested on actual field-derived tobacco-spiked samples after extraction with the QuEChERS method in order to evaluate matrix effects. Seven samples were assessed. Four of the samples (657-660) did not contain cypermethrin, while the rest three contained cypermethrin concentrations in the range of $1.5 \mathrm{up}$ to $2.0 \mu \mathrm{g} \mathrm{mL} \mathrm{m}^{-1}$ (Table 1). From the results of the HPLC analysis, we found that the percentage of recoveries of the spiked samples were between $75-85.7 \%$. Thus, we inferred that cypermethrin real concentrations in the extracts were ranging from 1.2 to $1.5 \mu \mathrm{g} \mathrm{mL}^{-1}$. From our biosensor results, no statistically significant differences in the responses of the 
four cypermenthrin-free samples were observed. On the contrary, when we compared the control samples with the respective cypermethrin-containing sample extracts, we detected significant variations in the bioelectric measurements, as shown in Figure 7. Indeed, the biosensor's response increased with the cypermethrin content in the sample extracts, whereas responses between cypermethrin-negative and -positive samples as well as between samples containing different levels of cypermethrin were statistically significant.

Table 1. Percentage recoveries from the high performance liquid chromatography(HPLC) analysis of the cypermethrin spiked tobacco leaves.

\begin{tabular}{ccccc}
\hline Sample & $\begin{array}{c}\text { Spiking Amount in 2 g of } \\
\text { Leaf Sample }(\mu \mathrm{g})\end{array}$ & $\begin{array}{c}\text { Spiking Level } \\
\left(\mu \mathrm{gL}^{-\mathbf{1}}\right)\end{array}$ & $\begin{array}{c}\text { Measured } \\
\left(\mu \mathrm{g} \mathrm{mL} \mathbf{L}^{-\mathbf{1}}\right)\end{array}$ & Mean Recovery \% \\
\hline 657 & 0 & 0 & 0 & 100 \\
\hline 658 & 0 & 0 & 0 & 100 \\
\hline 659 & 0 & 0 & 0 & 100 \\
\hline 660 & 0 & 0 & 0 & 100 \\
\hline 940 & 1.5 & 1.5 & 1.2 & 80 \\
\hline 941 & 1.75 & 1.75 & 1.5 & 85.7 \\
\hline 942 & 2 & 2 & 1.5 & 75 \\
\hline
\end{tabular}

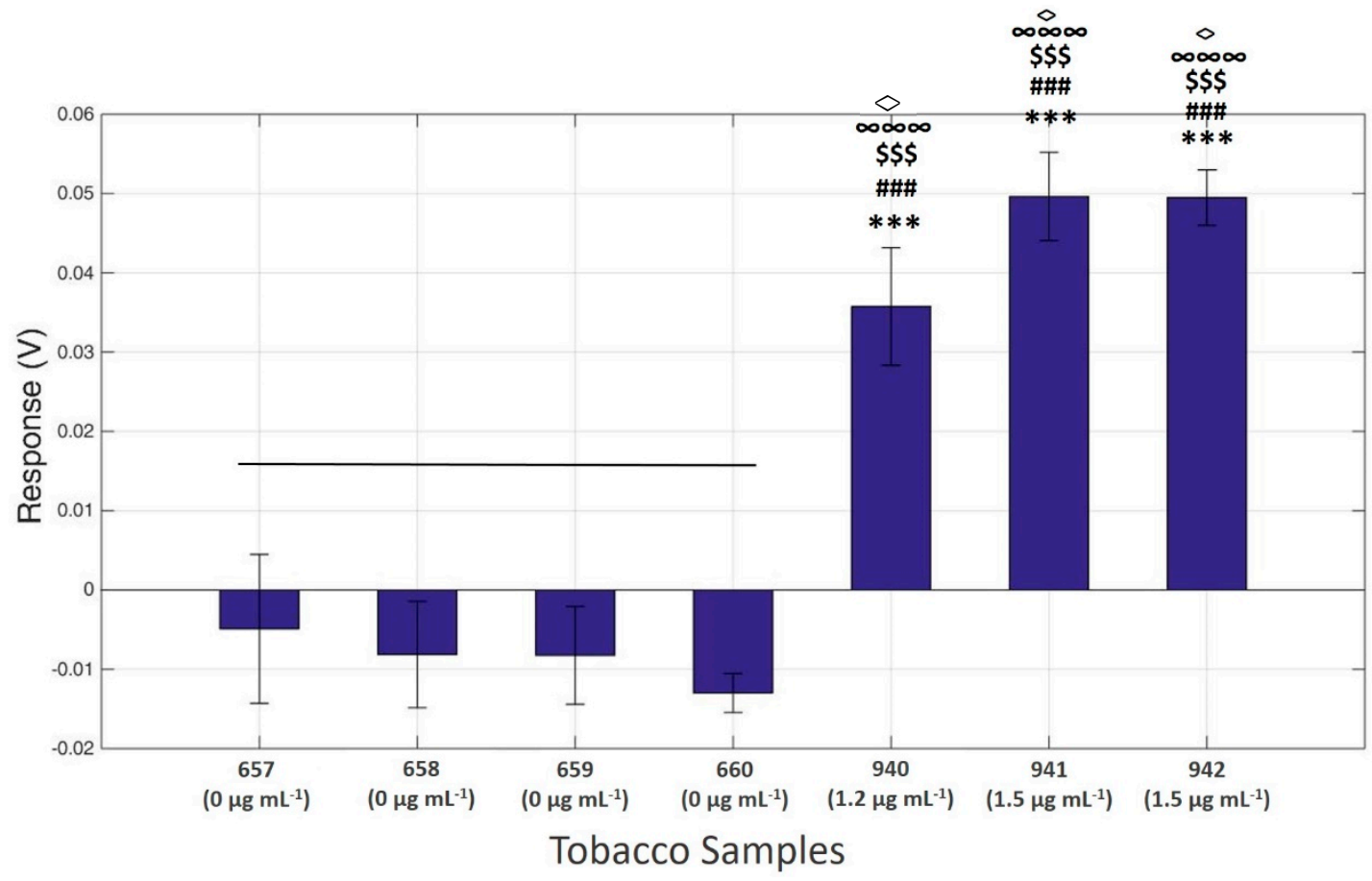

Figure 7. Neuroblastoma cell-based biosensor electrical responses after application of various extracts from tobacco samples (10\% methanol solution), including cypermethrin or not. The results are expressed as the mean values of five replications $\pm \mathrm{SD} \mu \mathrm{g} \mathrm{mL}^{-1}$. ${ }^{* *} p<0.001$ significantly different from sample 657, \#\#\# $p<0.001$ significantly different from sample $658, \$ \$ \$<0.001$ significantly different from sample 659, ${ }^{\infty 000} p<0.001$ significantly different from sample 660, $\diamond p<0.05$ significantly different from sample 940 . 


\section{Discussion}

Pesticides are utilized worldwide in order to prevent crops from damage as well as to augment their qualitative and quantitative traits. Research findings suggest that their use appears to have a significant impact on yield increase, yet more and more studies show that pesticides can be hazardous for both human and animal health. In addition, these compounds have continuous distribution and adversely affect nontarget organisms, due to their regular use. Between toxic pesticides, cypermethrin constitutes one of the most widely used and well-studied ones, applied in industries, buildings, domestic and agricultural fields. Due to its worldwide use, there is a great interest referring to cypermethrin evaluation in a safe range of utilization.

Thus, its accurate and prompt detection is a vital matter of concern. As mentioned in the introduction section, conventional analytical methods such as chromatography, though accurate and reliable are not suitable for high throughput routine analysis of target pesticides, in particular due to a number of drawbacks, such as time-consuming and labor-intensive processes and high cost per sample test, as well as the need of a central analytical testing facility [36]. On the contrary, the availability of novel, sensitive, specific, quick, and cheap solutions for the in situ detection of pesticide residues would give the opportunity to stakeholders (growers and purchasers of harvested material) to instantly determine the quality of the produce on site at a truly unprecedented scale [37,38].

In this study, cypermethrin determination in tobacco extracts was performed using a highly sensitive electrochemical neuroblastoma cell-based biosensor. Our findings indicated that application of various cypermethrin concentrations on SK-N-SH cell line exhibited a significantly decreasing response as insecticide levels raised, especially in the range of $1.0-1.5 \mu \mathrm{g} \mathrm{mL}^{-1}$. Neuroblastoma SK-N-SH cells were chosen due to their neuronal origin [39]. Muscle and neural cells are excitable cells by means of cellular categories capable of transiting from a resting to an excited state potential. The definition of a cell resting membrane potential is defined as the changes between electrical potential across the plasma membrane when that cell is in a nonexcited state [40]. Pyrethroid insecticides such as cypermethrin preferably bind to open neural sodium channels stabilizing thus an open state that causes prolonged currents. The channels activation leads to a rapid action potentials rising face [41]. The neuroblastoma biosensor responses reduced after treatment with combined concentrations of the tobacco alkaloid nicotine and $1.5 \mu \mathrm{g} \mathrm{mL} \mathrm{mL}^{-1}$ cypermethrin. As plain nicotine concentrations increased, depolarization phenomena were observed. On the contrary, when cypermethrin was introduced into the system, this negative motif was disrupted. Furthermore, the cellular bioelectric responses were altered, leading to a plateau at $3 \mu \mathrm{g} \mathrm{mL} \mathrm{m}^{-1}$ nicotine. In a large number of animal studies, it has been shown that nicotinic receptors expression was induced when small doses of nicotine were administered [42]. Moreover, other studies suggested the upregulation of nicotinic binding sites after nicotine chronic exposure $[43,44]$. Additionally, native nicotinic acetylcholine receptors of neuroblastoma SK-N-SH cells were able to partially maintain their activity during the chronic application of nicotine [45]. The biosensor's response against tobacco extracts spiked with cypermethrin concentrations showed statistically significant alterations in the responses when compared with the four cypermenthrin-free samples. However, the presence of cypermethrin in tobacco extracts resulted in a positive change of the biosensor's response, an observation which is opposite to the pattern established with cypermethrin standard solutions. This might be due to interference of various tobacco ingredients other than nicotine but also affecting SK-N-SH cells. In spite of this, the novel biosensor allowed for a clear discrimination between cypermethrin-free and cypermethrin-positive tobacco samples. In a previous study, total particulate matter from tobacco used for cigarette smoke revealed increased agonist binding to nicotinic acetylcholine receptors in comparison with plain nicotine indicating that tobacco non-nicotinic substances can elevate nicotinic acetylcholine subunits expression [46]. It must be emphasized that information on nicotine-cypermethrin biointeraction is scarce, if nonexistent. Therefore, the present study is a first step contributing to our understanding of said combined effects of these compounds on neural cells. 
The association between changes in the neuroblastoma membrane potential and the observed bioelectric biosensor's responses was corroborated by the observed changes in intracellular calcium efflux. Fluorescence measurements of fluo-3/acetoxymethyl ester (AM)-stained neuroblastoma fibroblasts have shown that the application of cypermethrin $\left(1.5 \mu \mathrm{g} \mathrm{mL}^{-1}\right)$ on SK-N-SH cells resulted in intracellular calcium efflux. Furthermore, incubation of the cell line with nicotine had also significant effects on calcium levels. Our findings indicated that low nicotine concentrations $\left(300 \mu \mathrm{g} \mathrm{mL} \mathrm{L}^{-1}\right) \mathrm{did}$ not affect cellular morphology and calcium levels compared to higher doses $\left(1500 \mu \mathrm{g} \mathrm{mL}^{-1}\right)$, which caused excessive cytotoxicity and depletion of calcium inventories. Previous studies suggested that chronic exposure to nicotine induces upregulation of nicotinic binding sites $[43,44]$, leading to increases as well as decreases in cellular responses such as intracellular calcium flux have been described [44,47-50].

\section{Conclusions}

In this study, a highly sensitive neuroblastoma cell-based electrochemical biosensor was developed for cypermethrin determination in tobacco extracts. Neuroblastoma SK-N-SH cells were used as the biorecognition element since they constitute a suitable system for the study of cell-membrane potential responses to pyrethroids. Moreover, electrochemical biosensors allow for the generation of a quantifiable signal, which can be readily transmitted from the field-testing site via the Internet to a central database or electronic invoicing platform. In this respect, the wider application of the biosensor approach presented here could revolutionize field-based, pesticide residue testing for tobacco growers, allowing for a much greater testing volume than currently feasible. As it stands, the proposed biosensor does not allow for the selective determination of cypermethrin vs other neuroactive pesticides. However, this can be improved by the employment of advanced time-series classifiers, such as artificial neural networks, which can be trained to recognize unique patterns of bioelectric responses to different pesticides in tobacco samples. In this context, in-depth study is needed to improve our system in terms of sensitivity, instrumentation and other related areas such as bioelectronics. The present study is only a proof-of-concept approach to the development of the novel biosensor, while extensive additional experimentation, including calibration curve, linear range of response, interferences, optimal $\mathrm{pH}$ and storage stability will be part of a future work. In the near future, these improvements will ultimately have a marked influence on the development of new biosensing strategies for pesticide analysis in the tobacco and related products' industry.

Author Contributions: Conceptualization, S.K. and P.A.R.; methodology, T.A. and S.M.; validation, T.A., S.M., N.-K.D.; investigation T.A., N.-K.D., S.M. and G.P.; data curation, G.P.; writing-original draft preparation, T.A., S.M., N.-K.D. and G.P.; writing-review and editing, P.A.R. and S.K.; visualization, P.A.R. and S.K.; supervision, P.A.R. and S.K.

Funding: This research received no external funding.

Conflicts of Interest: The authors declare no conflict of interest.

\section{References}

1. Bilal, M.; Rasheed, T.; Sosa-Hernández, J.E.; Raza, A.; Nabeel, F.; Iqbal, H.M.N. Biosorption: An Interplay between Marine Algae and Potentially Toxic Elements-A Review. Mar. Drugs 2018, 16, 65. [CrossRef] [PubMed]

2. Ullah, S.; Zuberi, A.; Alagawany, M.; Farag, M.R.; Dadar, M.; Karthik, K.; Tiwari, R.; Dhama, K.; Iqbal, H.M.N. Cypermethrin induced toxicities in fish and adverse health outcomes: Its prevention and control measure adaptation. J. Environ. Manag. 2017, 206, 863-887. [CrossRef] [PubMed]

3. Rahman, S.; Rahman, M.; Hossain, S. Cypermethrin residue analysis of fruit and soil samples in eggplant ecosystem in Bangladesh. Sci. Lett. 2015, 3, 138-141.

4. Drossopoulos, J.; Bouranis, D.; Kintzios, S.; Aivalakis, G.; Triposkoufi, A. Distribution profiles of selected micronutrients in oriental field-grown tobacco plants as affected by nitrogen fertilization. J. Plant Nutr. 1998, 21, 1391-1406. [CrossRef] 
5. Rodgman, A.; Perfetti, T.A. The Chemical Components of Tobacco and Tobacco Smoke; CRC Press: Boca Raton, FL, USA, 2013.

6. Klaassen, C.D.; Amdur, M.O.; Doull, J. Casarett \& Doull's Toxicology: The Basic Science of Poisons; McGraw-Hill: Toronto, ON, Canada, 1996.

7. Wolansky, M.J.; Harrill, J.A. Neurobehavioral toxicology of pyrethroid insecticides in adult animals: A critical review. Neurotoxicol. Teratol. 2008, 30, 55-78. [CrossRef]

8. Lawrence, J.L.; Casida, J.E. Pyrethroid toxicology:mouse intracerebral structure-toxicity relationships. Pestic. Biochem. Physiol. 1982, 18, 9-14. [CrossRef]

9. Romero, A.; Ares, I.; Ramos, E.; Castellano, V.; Martínez, M.; Martínez-Larrañaga, M.R.; Anadón, A.; Martínez, M.A. Evidence for dose-additive effects of a type II pyrethroid mixture. In vitro assessment. Environ. Res. 2015, 138, 58-66. [CrossRef]

10. Malkiewicz, K.; Koteras, M.; Folkesson, R.; Brzezinski, J.; Winblad, B.; Szutowski, M.; Benedikz, E. Cypermethrin alters Glial Fibrillary Acidic Protein levels in the rat brain. Environ. Toxicol. Pharmacol. 2006, 21,51-55. [CrossRef]

11. Raszewski, G.; Lemieszek, M.K.; Łukawski, K. Cytotoxicity induced by cypermethrin in human neuroblastoma cell line SH-SY5Y. Ann. Agric. Environ. Med. 2016, 23, 106-110. [CrossRef]

12. Romero, A.; Ramos, E.; Ares, I.; Castellano, V.; Martínez, M.; Martínez-Larrañaga, M.R.; Anadón, A.; Martínez, M.A. Oxidative stress and gene expression profiling of cell death pathways in alpha-cypermethrin-treated SH-SY5Y cells. Arch. Toxicol. 2016, 91, 2151-2164. [CrossRef]

13. Maurya, S.K.; Mishra, J.; Tripathi, V.K.; Sharma, R.; Siddiqui, M.H. Cypermethrin induces astrocyte damage: Role of aberrant $\mathrm{Ca}\left({ }^{2+}\right)$, ROS, JNK, P38, matrix metalloproteinase 2 and migration related reelin protein. Pestic. Biochem. Physiol. 2014, 111, 51-59. [CrossRef] [PubMed]

14. Soderlund, D. Molecular mechanisms of pyrethroid insecticide neurotoxicity: Recent advances. Arch. Toxicol. 2012, 86, 165-181. [CrossRef] [PubMed]

15. Meijer, M.; Dingemans, M.M.; Berg, M.V.D.; Westerink, R.H. Inhibition of voltage-gated calcium channels as common mode of action for (mixtures of) distinct classes of insecticides. Toxicol. Sci. 2014, 141, 103-111. [CrossRef] [PubMed]

16. Meijer, M.; Brandsema, J.A.; Nieuwenhuis, D.; Wijnolts, F.M.; Dingemans, M.M.; Westerink, R.H. Inhibition of Voltage-Gated Calcium Channels After Subchronic and Repeated Exposure of PC12 Cells to Different Classes of Insecticides. Toxicol. Sci. 2015, 147, 607-617. [CrossRef] [PubMed]

17. Costa, L.G. The neurotoxicity of organochlorine and pyrethroid pesticides. Handb. Clin. Neurol. 2015, 131, 135-148.

18. Hossain, M.M.; Liu, J.; Richardson, J.R. Pyrethroid Insecticides Directly Activate Microglia Through Interaction with Voltage-Gated Sodium Channels. Toxicol. Sci. 2017, 155, 112-123. [CrossRef]

19. Taju, G.; Majeed, S.A.; Nambi, K.S.; Farook, M.A.; Vimal, S.; Hameed, A.S.S. In vitro cytotoxic, genotoxic and oxidative stress of cypermethrin on five fish cell lines. Pestic. Biochem. Physiol. 2014, 113, 15-24. [CrossRef]

20. Mavrikou, S.; Flampouri, K.; Moschopoulou, G.; Mangana, O.; Michaelides, A.; Kintzios, S. Assessment of Organophosphate and Carbamate Pesticide Residues in Cigarette Tobacco with a Novel Cell Biosensor. Sensors 2008, 8, 2818-2832. [CrossRef]

21. Anastassiades, M.; Lehotay, S.J. Fast and easy multiresidue methods employing acetonitrile extraction/partitioning and "dispersive solid-phase extraction" for the determination of pesticide residues in produce. J. AOAC Int. 2003, 86, 412-413.

22. Lang, Q.; Han, L.; Hou, C.; Wang, F.; Liu, A. A sensitive acetylcholinesterase biosensor based on gold nanorods modified electrode for detection of organophosphate pesticide. Talanta 2016, 156, 34-41. [CrossRef]

23. Hassani, S.; Momtaz, S.; Vakhshiteh, F.; Maghsoudi, A.S.; Ganjali, M.R.; Norouzi, P.; Abdollahi, M. Biosensors and their applications in detection of organophosphorus pesticides in the environment. Arch. Toxicol. 2016, 91, 109-130. [CrossRef] [PubMed]

24. Moschopoulou, G.; Dourou, A.M.; Fidaki, A.; Kintzios, S. Assessment of pesticides cytoxicity by means of bioelectric profiling of mammalian cells. Environ. Nanotechnol. Monit. Manag. 2017, 8, 254-260. [CrossRef]

25. Kintzios, S.; Pistola, E.; Panagiotopoulos, P.; Bomsel, M.; Alexandropoulos, N.; Bem, F.; Ekonomou, G.; Biselis, J.; Levin, R. Bioelectric recognition assay (BERA). Biosens. Bioelectron. 2001, 16, 325-336. [CrossRef]

26. Flampouri, K.; Mavrikou, S.; Kintzios, S.; Miliadis, G.; Aplada-Sarlis, P. Development and validation of a cellular biosensor detecting pesticide residues in tomatoes. Talanta 2010, 80, 1799-1804. [CrossRef] 
27. Ferentinos, K.P.; Yialouris, C.P.; Blouchos, P.; Moschopoulou, G.; Kintzios, S. Pesticide Residue Screening Using a Novel Artificial Neural Network Combined with a Bioelectric Cellular Biosensor. BioMed Res. Int. 2013, 2013, 813519. [CrossRef]

28. Standard, B. Foods of Plant Origin—Determination of Pesticide Residues Using GC-MS and/or LC-MS/MS Following Acetonitrile Extraction/Partitioning and Clean-up by Dispersive SPE-QuEChERS Method. Available online: https://standards.globalspec.com/std/10387667/EN\%2015662 (accessed on 1 May 2018).

29. Instruments, T. Amplifiers for Any System. Available online: https://www.ti.com/amplifier-circuit/overview. html (accessed on 10 May 2019).

30. Ungvari, Z.; Labinskyy, N.; Mukhopadhyay, P.; Pinto, J.T.; Bagi, Z.; Ballabh, P.; Zhang, C. Resveratrol attenuates mitochondrial oxidative stress in coronary arterial endothelial cells. Am. J. Physiol. Heart Circ. 2009, 297, H1876-H1881. [CrossRef]

31. Tambwekar, K.R.; Kakariya, R.B.; Garg, S. A validated high performance liquid chromatographic method for analysis of nicotine in pure form and from formulations. J. Pharm. Biomed. Anal. 2003, 32, 441-450. [CrossRef]

32. Fardous, Z.; Islam, M.N.; Hoque, S.M.; Chowdhury, M.A.Z.; Rahman, M.A. Determination of some selected pesticide residues in tomato from different locations of Bangladesh. Int. J. Sustain. Agric. Technol. 2007, 3, 4-7.

33. Chowdhury, A.Z.; Jahan, S.A.; Islam, M.N.; Moniruzzaman, M.; Alam, M.K.; Zaman, M.A.; Karim, N.; Gan, S.H. Occurrence of organophosphorus and carbamate Pesticide residues in surface water samples from the Rangpur district of Bangladesh. Bull. Environ. Contam. Toxicol. 2012, 89, 202-207. [CrossRef]

34. Mahboub, B.; Mohammad, A.B.; Nahlé, A.; Vats, M.; Assaf, O.A.; Al-Zarooni, H. Analytical Determination of Nicotine and Tar Levels in Various Dokha and Shisha Tobacco Products. J. Anal. Toxicol. 2018, 42, 496-502. [CrossRef]

35. Taghavi, S.; Khashyarmanesh, Z.; Moalemzadeh-Haghighi, H. Nicotine content of domestic cigarettes, imported cigarettes and pipe tobacco in iran. Addict. Health 2012, 4, 28-35. [PubMed]

36. Pundir, C.S.; Chauhan, N. Acetylcholinesterase inhibition-based biosensors for pesticide determination: A review. Anal. Biochem. 2012, 429, 19-31. [CrossRef] [PubMed]

37. Verma, N.; Bhardwaj, A. Biosensor technology for pesticides-A review. Appl. Biochem. Biotechnol. 2015, 175, 3093-3119. [CrossRef] [PubMed]

38. Liu, S.; Zheng, Z.; Li, X. Advances in pesticide biosensors: Current status, challenges, and future perspectives. Anal. Bioanal. Chem. 2013, 405, 63-90. [CrossRef] [PubMed]

39. Biedler, J.L.; Roffler-Tarlov, S.; Schachner, M.; Freedman, L.S. Multiple neurotransmitter synthesis by human neuroblastoma cell lines and clones. Cancer Res. 1978, 38, 3751-3757. [PubMed]

40. Chrysafides, S.M.; Sharma, S. Physiology, Resting Potential; StatPearls: Treasure Island, FL, USA, 2019.

41. Silver, K.S.; Du, Y.; Nomura, Y.; Oliveira, E.E.; Salgado, V.L.; Zhorov, B.S.; Dong, K. Voltage-Gated Sodium Channels as Insecticide Targets. Adv. Insect Physiol. 2014, 46, 389-433.

42. Ryan, R.E.; Ross, S.A.; Drago, J.; Loiacono, R.E. Dose-related neuroprotective effects of chronic nicotine in 6-hydroxydopamine treated rats, and loss of neuroprotection in alpha4 nicotinic receptor subunit knockout mice. Br. J. Pharmacol. 2001, 132, 1650-1656. [CrossRef]

43. Peng, X.; Gerzanich, V.; Anand, R.; Wang, F.; Lindstrom, J. Chronic nicotine treatment up-regulates alpha3 and alpha7 acetylcholine receptor subtypes expressed by the human neuroblastoma cell line SH-SY5Y. Mol. Pharmacol. 1997, 51, 776-784. [CrossRef]

44. Wang, F.; Nelson, M.E.; Kuryatov, A.; Olale, F.; Cooper, J.; Keyser, K.; Lindstrom, J. Chronic nicotine treatment up-regulates human alpha3 beta2 but not alpha3 beta4 acetylcholine receptors stably transfected in human embryonic kidney cells. J. Biol. Chem. 1998, 273, 28721-28732. [CrossRef]

45. Sokolova, E.; Matteoni, C.; Nistri, A. Desensitization of neuronal nicotinic receptors of human neuroblastoma SH-SY5Y cells during short or long exposure to nicotine. Br. J. Pharmacol. 2005, 146, 1087-1095. [CrossRef]

46. Ambrose, V.; Miller, J.H.; Dickson, S.J.; Hampton, S.; Truman, P.; Lea, R.A.; Fowles, J. Tobacco particulate matter is more potent than nicotine at upregulating nicotinic receptors on SH-SY5Y cells. Nicotine Tob. Res. 2007, 9, 793-799. [CrossRef] [PubMed]

47. Buisson, B.; Bertrand, D. Chronic exposure to nicotine upregulates the human (alpha)4(beta)2 nicotinic acetylcholine receptor function. J. Neurosci. 2001, 21, 1819-1829. [CrossRef] [PubMed] 
48. Hsu, Y.N.; Amin, J.; Weiss, D.S.; Wecker, L. Sustained nicotine exposure differentially affects alpha 3 beta 2 and alpha 4 beta 2 neuronal nicotinic receptors expressed in Xenopus oocytes. J. Neurochem. 1996, 66, 667-675. [CrossRef] [PubMed]

49. Molinari, E.J.; Delbono, O.; Messi, M.L.; Renganathan, M.; Arneric, S.P.; Sullivan, J.P.; Gopalakrishnan, M. Up-regulation of human alpha7 nicotinic receptors by chronic treatment with activator and antagonist ligands. Eur. J. Pharmacol. 1998, 347, 131-139. [CrossRef]

50. Ridley, D.L.; Pakkanen, J.; Wonnacott, S. Effects of chronic drug treatments on increases in intracellular calcium mediated by nicotinic acetylcholine receptors in SH-SY5Y cells. Br. J. Pharmacol. 2002, 135, 1051-1059. [CrossRef] [PubMed]

(C) 2019 by the authors. Licensee MDPI, Basel, Switzerland. This article is an open access article distributed under the terms and conditions of the Creative Commons Attribution (CC BY) license (http://creativecommons.org/licenses/by/4.0/). 